\title{
Immunochemical Study of Uroporphyrinogen Decarboxylase in a Patient with Mild Hepatoerythropoietic Porphyria
}

\author{
H. Fujita, S. Sassa, A. C. Toback, and A. Kappas \\ The Rockefeller University Hospital and Columbia Presbyterian Medical Center, New York 10021
}

\begin{abstract}
Hepatoerythropoietic porphyria (HEP) is due to a marked deficiency of uroporphyrinogen (URO) decarboxylase, a cytosolic enzyme in the heme biosynthetic pathway. Using a radioimmunoassay method, we determined the concentration of URO decarboxylase protein in erythrocytes from a patient with mild HEP and found that the enzyme protein concentration had markedly decreased to $<7 \%$ of the normal controls. This finding, however, was in contrast to the enzyme activity in the patient's erythrocytes, which was $16 \%$ of normal control levels and different from previously reported HEP cases in that erythrocytes in our patient contained disproportionately elevated URO decarboxylase activity in comparison to its immunoreactive material. Our finding suggests the possibility of a mutant isozyme in this patient that is not immunoreactive with an antibody raised against the normal enzyme.
\end{abstract}

\section{Introduction}

Uroporphyrinogen (URO) ${ }^{1}$ decarboxylase (EC 4.1.1.37) is a cytosolic enzyme involved in the biosynthesis of heme. It catalyzes the sequential removal of four carboxyl groups of the carboxymethyl side chains of uroporphyrinogen to yield coproporphyrinogen (1). Decreased enzyme activity has been demonstrated in tissues from patients with porphyria cutanea tarda (PCT) and hepatoerythropoietic porphyria (HEP) (2). A greater deficiency of URO decarboxylase activity was noted in the latter (3) than that in the former group. 15 patients with HEP have been reported to date in the world's literature, and marked deficiency of URO decarboxylase activity was demonstrated in nine patients (4-15). Previous immunochemical studies on URO decarboxylase in HEP patients showed that there were two groups of patients, one displaying the enzyme deficiency with cross-immunoreactive material (CRIM) positive mutation (16) and the other with CRIM negative mutation (12).

In the present study, we describe another type of URO decarboxylase mutation occurring in a family with HEP, in which

Received for publication 29 September 1986 and in revised form 28 January 1987.

1. Abbreviations used in this paper: ALA, $\delta$-aminolevulinic acid; CRIM, cross-immunoreactive material; HEP, hepatoerythropoietic porphyria; PCT, porphyria cutanea tarda; URO, uroporphyrinogen.

J. Clin. Invest.

(C) The American Society for Clinical Investigation, Inc.

$0021-9738 / 87 / 05 / 1533 / 05 \quad \$ 1.00$

Volume 79, May 1987, 1533-1537 erythrocyte URO decarboxylase activity was substantially higher than expected for the level of the immunoreactive enzyme protein measured.

\section{Methods}

Case report. The proband was a 31 -yr-old man with HEP who has been previously described (17).

Chemicals. Pentacarboxylate porphyrin I and $\delta$-aminolevulinic acid (ALA) were obtained from Porphyrin Products, Logan, UT, and Sigma Chemical Co., St. Louis, MO, respectively. A goat anti-rabbit IgG was purchased from HyClone Ltd., Logan, UT. Na ${ }^{125}$ I (specific radioactivity: $16.1 \mathrm{mCi} / \mu \mathrm{g}$ iodine) was obtained from Amersham Co., Amersham, U.K.

Enzyme purification and preparation of antibodies. URO decarboxylase and ALA dehydratase were purified to homogeneity from normal human erythrocytes according to methods published previously $(1,18)$. The purified enzyme preparations were labeled with ${ }^{125}$ I as previously described (19). Specific radioactivities of ${ }^{125}$ I-labeled URO decarboxylase and $\mathrm{ALA}$ dehydratase were $5 \mu \mathrm{Ci} / \mu \mathrm{g}$ protein and $4 \mu \mathrm{Ci} / \mu \mathrm{g}$ protein, respectively.

An anti-human URO decarboxylase IgG and an anti-human ALA dehydratase IgG were prepared in rabbits and isolated from sera as described previously $(1,20) . \sim 50 \%$ of the labeled antigen was bound to the IgG at dilutions of $1: 10,000$ and 1:30,000 for URO decarboxylase and ALA dehydratase, respectively.

Enzyme assays. Activities of URO decarboxylase and ALA dehydratase were determined according to methods reported previously (1, $21) .1 \mathrm{U}$ of URO decarboxylase activity was defined as $1 \mathrm{nmol}$ coproporphyrinogen formed at $37^{\circ} \mathrm{C}$ per $\mathrm{h}$.

Radioimmunoassays. ALA dehydratase concentration was determined by the method of Fujita et al. (19). Radioimmunoassay (RIA) of URO decarboxylase activity was also carried out in a manner similar to that for ALA dehydratase. All determinations were carried out in triplicate. The binding of the antibody with the radiolabeled enzyme was expressed as the percentage of the bound fraction to the radioactivity of the same fraction in the absence of unlabeled antigen $\left(B / B_{0}\right)$. The lowest detection limit was $1.6 \mathrm{ng} /$ assay for URO decarboxylase and 1.0 $\mathrm{ng} /$ assay for ALA dehydratase (22). Specific activity was calculated based on the enzyme activity and enzyme concentration determined in the identical specimen.

\section{Results}

RIA of URO decarboxylase. A typical calibration curve for the RIA on URO decarboxylase is shown in Fig. 1. Enzyme concentrations ranging from 1.6 to $10,000 \mathrm{ng} /$ assay can be determined. Both the purified enzyme (solid curve) and lysates (dotted curve) showed a parallel curve, indicating that an accurate estimation of the enzyme concentration in lysates can be made.

The reproducibility of the RIA was examined by comparing intra- and interassay variations (Table I). Coefficients of variation for the intraassay comparison using two blood samples contain- 


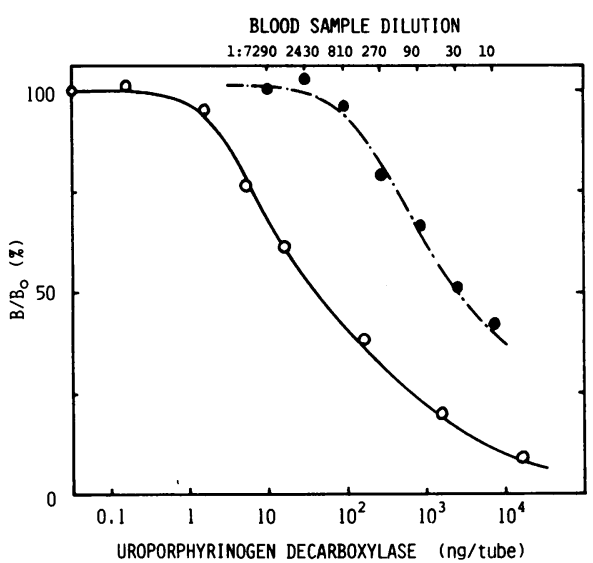

Figure 1. RIA titration curves for URO decarboxylase concentrations. Typical titration curves with purified enzyme (open circle) and erythrocyte lysates (closed circle) are shown. Each data point represents the mean of triplicate assays.

ing 15.75 and $59.71 \mathrm{ng}$ URO decarboxylase per assay were $7.89 \%$ and $3.34 \%$, respectively. Coefficients of variation for the interassay comparison were 4.60 and $4.80 \%$ for 15.42 and $17.64 \mathrm{ng}$ enzyme per assay, respectively.

The recovery of the added enzyme to blood specimens was examined to determine the accuracy of the RIA. When $51.9 \mathrm{ng}$ of the purified enzyme was added to blood with five different concentrations of URO decarboxylase (15.9-59.8 ng), an average of $100.0 \pm 5.93 \%$ of the added enzyme was detected. Addition of the purified enzyme at four different concentrations (17.3-467 $\mathrm{ng} /$ assay) to lysates containing $35.4 \mathrm{ng}$ of URO decarboxylase also showed an excellent recovery of the added enzyme (average recovery, $96.3 \pm 5.2 \%$ ). These results indicate that the method is suitable for assaying the enzyme concentration in lysates.

Table I. Intra- and Interassay Variations of Quantitation of URO Decarboxylase by RIA

\begin{tabular}{|c|c|c|c|c|}
\hline \multirow[b]{3}{*}{ No. } & \multicolumn{4}{|c|}{ URO decarboxylase } \\
\hline & \multicolumn{2}{|c|}{ Intraassay comparison } & \multicolumn{2}{|c|}{ Interassay comparison } \\
\hline & Sample A & Sample B & Sample C & Sample D \\
\hline & ng/assay & ng/assay & ng/assay & ng/assay \\
\hline 1 & 15.49 & 59.95 & 15.85 & 17.82 \\
\hline 2 & 15.85 & 58.72 & 15.81 & 18.13 \\
\hline 3 & 13.80 & 57.78 & 14.60 & 16.97 \\
\hline 4 & 16.60 & 62.39 & - & - \\
\hline 5 & 17.01 & - & - & - \\
\hline Mean & 15.75 & 59.71 & 15.42 & 17.64 \\
\hline SD & 1.24 & 1.99 & 0.71 & 0.60 \\
\hline CV (\%) & 7.89 & 3.34 & 4.60 & 4.80 \\
\hline
\end{tabular}

URO decarboxylase concentrations in blood samples A and B were determined simultaneously in quintuplicate and quadruplicate, respectively; while determinations on samples $C$ and $D$ were carried out on three different occasions. SD, standard deviation; CV, coefficient of variation.
URO decarboxylase activity in erythrocytes and in the liver. Erythrocyte URO decarboxylase activity was examined in three normal adult subjects, the proband, his six family members, and four normal adult controls in the same assay as a function of incubation periods (Table II). All subjects showed a constant rate of product formation up to $20 \mathrm{~min}$ of incubation. The initial velocity of the enzyme reaction calculated for the normal control enzyme was $1.48 \mathrm{nmol} / \mathrm{min}$ per $\mathrm{ml} \mathrm{RBC}$, whereas it was 0.23 $\mathrm{nmol} / \mathrm{min}$ per $\mathrm{ml} \mathrm{RBC}$ for the proband's enzyme. Except the proband's wife, who had the velocity of $1.10 \mathrm{nmol} / \mathrm{min}$ per $\mathrm{ml}$ RBC, other members of the family had markedly decreased values ranging from 0.68 to $0.85 \mathrm{nmol} / \mathrm{min}$ per $\mathrm{ml} \mathrm{RBC}$. Thus the enzyme activity in the proband based on the initial velocity was $16 \%$ of the control, whereas his parents and the three children had decreased URO decarboxylase activity, ranging $46-57 \%$ of the control. These data indicate that both parents and the three children of the proband were heterozygous for URO decarboxylase deficiency. The enzyme incubation was also carried out using pentacarboxylate porphyrinogen III as substrate at $\mathrm{pH} 6.9$ for the normal control enzyme and the younger son's enzyme. The results were essentially comparable with those obtained using pentacarboxylate porphyrinogen I as substrate at $\mathrm{pH} 6.0$, except that the rates were higher with the III isomer (data not shown).

The enzyme activity in a liver biopsy specimen from the proband $(0.009 \mathrm{U} / \mathrm{mg}$ protein) was significantly lower than that in the nonporphyric control subjects $(0.463 \pm 0.030 \mathrm{U} / \mathrm{mg}$ protein, $n=9$ ).

Erythrocyte URO decarboxylase concentration. Concentrations of URO decarboxylase in heterozygous gene carriers, i.e., both parents and the three children, were $52 \pm 10.4 \%$ of the control. The amount of enzyme protein in the proband's erythrocyte was below the detection level by RIA. This observation was consistent with the earlier results in the proband's erythrocytes that were determined by using Rocket immunoassay $(<5 \%$ of the

Table II. Erythrocyte URO Decarboxylase Activity and Its Concentration in a Family with HEP

\begin{tabular}{|c|c|c|c|}
\hline \multirow[b]{2}{*}{ Subject } & \multicolumn{3}{|c|}{ URO decarboxylase } \\
\hline & Protein & Sp act* & Initial velocity \\
\hline & $\mu g / m l R B C$ & U/ug enzyme & $\mathrm{nmol} / \mathrm{min} \cdot \mathrm{ml} \mathrm{RBC}$ \\
\hline Father (62 yr) & 9.7 & 5.7 & 0.68 \\
\hline Mother (60 yr) & 11.0 & 5.1 & 0.85 \\
\hline Proband ( $31 \mathrm{yr})$ & ND & $>12.0$ & 0.23 \\
\hline Wife (30 yr) & 26.5 & 3.3 & 1.10 \\
\hline Elder son $(7 \mathrm{yr})$ & 13.3 & 3.8 & 0.84 \\
\hline Daughter (4 yr) & 9.3 & 4.9 & 0.76 \\
\hline \multicolumn{4}{|l|}{ Younger son } \\
\hline (9 mo) & 23.8 & 3.3 & 0.71 \\
\hline Control $(n=5)$ & $25.8 \pm 1.7^{\ddagger}$ & $3.0 \pm 0.3^{\ddagger}$ & $1.48 \pm 0.13^{\ddagger 8}$ \\
\hline
\end{tabular}

Initial velocity was calculated based on product formation during the first 20 min of incubation. * Sp act was calculated based on the enzyme activity after $60 \mathrm{~min}$ of incubation (17) and the enzyme protein concentration in the same sample. ${ }^{\ddagger}$ Mean \pm SD. ${ }^{8} n=3$. RBC, red blood cells. ND, not detectable. The lowest limit of detection was 1.6 $\mathrm{ng} /$ assay on $1.8 \mu \mathrm{g} / \mathrm{ml}$ erythrocytes. 
control) (17). There was insufficient material from the liver biopsy for RIA assays.

The calculated specific activity, based on the enzyme activity and the enzyme concentration, demonstrated the discrepancy $(P<0.01)$ between that of normal subjects $(3.0 \pm 0.30 \mathrm{U} / \mu \mathrm{g}$ enzyme, $n=5)$ and heterozygous carriers $(4.6 \pm 0.44 \mathrm{U} / \mu \mathrm{g}$ enzyme, $n=5$ ) in the family as well as the proband (> $12.1 \mathrm{U} / \mu \mathrm{g}$ enzyme). The inability to detect the enzyme concentration in the proband was not due to an interfering substance in the RIA. This was shown by an experiment in which the added purified enzyme (17.3-467 ng/assay) was completely recovered (> 95\%).

Erythrocyte ALA dehydratase concentration. Erythrocyte ALA dehydratase concentrations were also determined to investigate whether the URO decarboxylase deficiency is a specific gene defect in this family. ALA dehydratase concentrations in the proband, the father and the mother were 245,151 , and 142 $\mu \mathrm{g} / \mathrm{ml}$ erythrocyte, respectively, and they were all within normal range (168 $\pm 58 \mu \mathrm{g} / \mathrm{ml}$ erythrocytes, $n=16)(23)$.

\section{Discussion}

The results of this study confirm that erythrocyte URO decarboxylase activity and the enzyme protein are markedly decreased in patients with HEP. Enzyme activity expressed as the initial reaction velocity in erythrocytes of the proband was, however, only $\sim 16 \%$ of normal controls, unusually high for HEP (Table III). Nonetheless the proband can be considered a homozygote for URO decarboxylase deficiency, because erythrocytes from both parents displayed enzyme activity significantly lower (46\% and $57 \%$ ) than that of normal controls. In addition to his parents, the three children of the proband had abnormally low URO decarboxylase activity (48-57\% of normal controls). The third child had an initial velocity of URO decarboxylase that was half that of the control enzyme. The enzymatic deficiency in this family was probably specific for URO decarboxylase, because ALA dehydratase concentration was normal in the proband and in his parents.

The proband was unique in several respects: $(a)$ his clinical picture was unusually mild for HEP (17), (b) the URO decarboxylase deficiency in erythrocytes was only partial, despite the homozygosity of the patient, and (c) he had offspring. Although 15 cases of HEP have been reported so far (Table III), no patients with children have been reported except for the present case.

In contrast to the mild deficiency of URO decarboxylase activity in the proband's erythrocytes, the level of the immunoreactive enzyme protein in erythrocytes was undetectable, despite the use of a highly sensitive and specific RIA that can detect enzyme activity of $\sim 7 \%$ of the normal control level. Thus the activity/mass ratio of URO decarboxylase in the proband was markedly elevated ( $>12$ vs. a normal range of $3.0 \pm 0.30, n=5$ ). Not only the proband, but also his parents, elder son, and daughter had abnormally elevated activity/mass ratios $(4.9 \pm 0.79$, $n=4)$ vs. normal controls $(3.0 \pm 0.30, n=5)$. These findings differ from the results of earlier studies of patients with HEP in whom both CRIM (-) and CRIM (+) mutation of URO decarboxylase had been reported (Table III). In CRIM (-) patients, the activity/mass ratio was the same as in normal controls, whereas in CRIM (+) patients, the ratio was lower than the normal value (Table III). Because the proband and the four family members with URO decarboxylase deficiency had an ab-

Table III. Abnormalities in URO Decarboxylase and Porphyrins in 16 Patients with HEP

\begin{tabular}{|c|c|c|c|c|c|c|c|c|}
\hline \multirow[b]{3}{*}{ Case } & \multirow[b]{3}{*}{ Author } & \multirow[b]{3}{*}{ Age } & \multirow[b]{3}{*}{ Sex } & \multirow[b]{3}{*}{ Onset } & \multicolumn{3}{|l|}{ Erythrocyte } & \multirow[b]{3}{*}{ References } \\
\hline & & & & & \multicolumn{2}{|l|}{ URO decarboxylase } & \multirow[b]{2}{*}{ Protoporphyrin } & \\
\hline & & & & & Activity & Activity/mass ratio* & & \\
\hline & & $y r$ & & & \% of normal control & ratio to normal control & fold ${ }^{*}$ & \\
\hline 1 & Gunther & 16 & $F$ & $18 \mathrm{mo}$ & - & - & 18 & 4 \\
\hline 2 & Aguade et al. & 42 & $\mathrm{~F}$ & $2 \mathrm{yr}$ & 6.9 & - & 4 & 3,5 \\
\hline 3 & Hofstad et al. & 4 & $\mathbf{M}$ & At birth & - & - & 9.5 & 6 \\
\hline 4 & Brenan & 3 & $\mathbf{F}$ & $6 \mathrm{mo}$ & $8^{\S}$ & - & $6-11$ & 3,7 \\
\hline 5 & Aguade et al. & 8 & $\mathrm{~F}$ & $8 \mathrm{mo}$ & 6.9 & - & $3-5$ & 3,8 \\
\hline 6 & Simon et al. & 60 & $\mathbf{M}$ & Early childhood & - & - & $3-5$ & 9 \\
\hline 7 & Simon et al. & 57 & $\mathrm{~F}$ & Early childhood & - & - & 12 & 9 \\
\hline 8 & Honigsmann \& Reidel & 63 & $\mathrm{~F}$ & Early childhood & - & - & $3-5$ & 10 \\
\hline 9 & Day \& Strauss & 12 & $\mathbf{M}$ & $3 \mathrm{yr}$ & - & - & 8 & 11 \\
\hline 10 & de Verneuil et al. & 7 & $\mathbf{F}$ & At birth & 5.2 & 1 & 9 & 12 \\
\hline 11 & de Verneuil et al. & 7 & $\mathbf{F}$ & At birth & 5.2 & 1 & 8 & 12 \\
\hline 12 & Lazaro et al. & 2 & $\mathrm{~F}$ & $1 \mathrm{yr}$ & $2.8-3.2$ & - & 7 & 13,15 \\
\hline 13 & Lim \& Poh-Fitzpatrick & 7 & $\mathbf{M}$ & $3 \mathrm{yr}$ & 13.6 & $<1$ & 15 & 14,16 \\
\hline 14 & Lim \& Poh-Fitzpatrick & 9 & $\mathbf{M}$ & $4 \mathrm{yr}$ & 8.8 & $<1$ & 10 & 14,16 \\
\hline 15 & Bundino et al. & 10 & $\mathbf{M}$ & $1 \mathrm{yr}$ & 7.3 & - & - & 15,24 \\
\hline 16 & Toback et al. & 31 & $\mathbf{M}$ & $6 \mathrm{yr}$ & 28 & $>1$ & 5 & 17 \\
\hline
\end{tabular}

*Expressed in comparison with the mean for normal controls. ${ }^{\ddagger}$ Increases of erythrocyte protoporphyrin (-fold) in comparison with the upper limit of the normal range. ${ }^{\S}$ Measured in fibroblasts. 
normally elevated activity/mass ratio, it appears that the abnormality of URO decarboxylase in this family represents another type of mutation in which the immunoreactive enzyme protein is disproportionately lost compared with its catalytic activity. Our findings suggest that the erythrocyte URO decarboxylase of these four subjects constitutes an enzyme that has reduced reactivity with an antibody prepared against the normal enzyme protein.

In this study, an RIA method specific for URO decarboxylase was used to quantitate the enzyme protein. For immunochemical studies of PCT or HEP, rocket immunoelectrophoresis or enzyme-linked immunoadsorbent assays (ELISA) have been used to quantitate the enzyme protein. Most studies have used a partially purified enzyme preparation from erythrocytes for analysis that might compromise the interpretation of results. ELISA is sensitive; however, it is difficult with this method to make a very accurate quantitation of enzyme protein. In contrast, RIA can be performed using unprocessed lysates or tissue homogenates, and offers an excellent sensitivity and accuracy for the quantitation of enzyme protein.

In contrast to the significant URO decarboxylase activity in erythrocytes ( $28 \%$ of the control based on total product formation after 60 min of incubation (17), or $16 \%$ of the control based on the initial velocity [Table II]), the enzyme activity in a biopsied specimen of the liver from the patient was only $2 \%$ of the control. It is not clear why the proband had mild clinical symptoms despite the nearly complete absence of URO decarboxylase activity in his liver.

Three possibilities need to be considered to explain the observed discrepancy of URO decarboxylase activity between erythrocytes and the liver. Firstly, there may be a tissue-specific transcriptional activation of the URO decarboxylase gene as recently reported by Romeo et al. (25). These authors noted that the level of URO decarboxylase mRNA is markedly elevated in erythroid cells in comparison to non-erythroid cells. Secondly, the mutant enzyme may have an abnormally increased catalytic activity, although there is no known instance for such a mutation among heme pathway enzymes. Thirdly, the mutated URO decarboxylase may undergo accelerated degradation as shown by de Verneuil et al. (26). Although their findings were made on the enzyme from a patient with CRIM (-) HEP, a similar situation might apply to our patient who had an abnormally decreased CRIM. The latter may have important implications for degradation of the enzyme in the liver, e.g., this process leading to an almost complete loss of the enzyme in the liver of our patient, where intracellular proteolysis is highly active. Now that the complementary DNA for URO decarboxylase has been cloned $(25,26)$, these questions have become amenable to resolution.

\section{Acknowledgments}

We are grateful to Drs. J. Schechter, M. B. Poh-Fitzpatrick, and L. Harber for referring the patient and his family members to us; to Dr. R. A. Galbraith for helping us obtain a liver biopsy from the patient, and to Dr. David H. van Thiel and Dr. Brian E. Hainline for providing us with nonporphyric control liver samples removed from patients who underwent liver transplantation. We are also grateful to Ms. L. Garbaczewski for her excellent technical assistance and Ms. J. A. Brighton for preparation of the manuscript.
This work was supported in part by United States Public Health Service grants DK-32890 and ES-01055.

\section{References}

1. de Verneuil, H., S. Sassa, and A. Kappas. 1983. Purification and properties of uroporphyrinogen decarboxylase from human erythrocytes. J. Biol. Chem. 258:2454-2460.

2. Kappas, A., S. Sassa, and K. E. Anderson. 1983. The porphyrias. In Metabolic Basis of Inherited Disease. J. B. Stanbury, J. B. Wyngaarden, D. S. Fredrickson, J. L. Goldstein, and M. S. Brown, editors. McGrawHill Book Co., New York. 1301-1384.

3. Elder, G. H., S. G. Smith, C. Herrero, M. Lecha, J. M. Mascaro, A. M. Muniesa, D. B. Czarnecki, J. Brenan, V. Poulos, and R. E. de Salamanca. 1981. Hepatoerythropoietic porphyria: a new uroporphyrinogen decarboxylase defect or homozygous porphyria cutanea tarda? Lancet. i:916-919.

4. Gunther, W. W. 1967. The porphyrias and erythropoietic protoporphyria: an usual case. Australas. J. Dermatol. 9:23-30.

5. Aquade, J. P., A. Castells, A. Indacochea, and J. Rodes. 1969. A case of biochemically unclassifiable hepatic porphyria. Br. J. Dermatol. 81:270-275.

6. Hofstad, F., M. Seip, and L. Eriksen. 1973. Congenital erythropoietic porphyria with a hitherto undescribed porphyrin pattern. Acta Paediatr. Scand. 62:380-384.

7. Brenan, J. A. 1974. Atypical erythropoietic protoporphyria. Aust. J. Dermatol. 15:36.

8. Aguade, J. P., C. Herrero, J. Almeida, A. Castells Mas, J. Ferrando, J. de Asprer, A. Palou, and A. Gimenez. 1975. Porphyrie hepato-erythrocytaire. Une nouvelle forme de porphyrie. Ann. Dermatol. Syphiligr. 102:129-136.

9. Simon, N., G. Y. Berko, and I. Schneider. 1977. Hepato-erythropoietic porphyria presenting as scleroderma and acrosclerosis in a sibling pair. Br. J. Dermatol. 96:663-668.

10. Honigsmann, H., and K. Reichel. 1979. Hepatoerythrozytare porphyrie. Hautarzt. 30:95-97.

11. Day, R. S., and P. C. Strauss. 1982. Severe cutaneous porphyria in a 12-year-old boy. Arch. Dermatol. 118:663-667.

12. de Verneuil, H., C. Beaumont, J.-C. Deybach, Y. Nordmann, Z. Sfar, and R. Kastally. 1984. Enzymatic and immunological studies of uroporphyrinogen decarboxylase in familial porphyria cutanea tarda and hepatoerythropoietic porphyria. Am. J. Hum. Genet. 36:613-622.

13. Lazaro, P., R. E. de Salamanca, G. H. Elder, M. L. Villaseca, S. Chinarro, and G. Jaqueti. 1984. Is hepatoerythropoietic porphyria a homozygous form of porphyria cutanea tarda? Inheritance of uroporphyrinogen decarboxylase deficiency in a Spanish family. Br. J. Dermatol. 110:613-617.

14. Lim, H. W., and M. B. Poh-Fitzpatrick. 1984. Hepatoerythroporphyria: a variant of childhood-onset porphyria cutanea tarda. J. Am. Acad. Dermatol. 11:1103-1111.

15. de Verneuil, H., C. Beaumont, B. Grandchamp, L. N. Phung, and Y. Nordmann. 1986. Molecular heterogeneity of uroporphyrinogen decarboxylase deficiency in hepatoerythropoietic porphyria. In Porphyrins and Porphyrias. Y. Nordmann, editor. John Libbey Eurotext, Paris. 201-208.

16. Sassa, S., H. de Verneuil, K. E. Anderson, and A. Kappas. 1983. Purification and properties of human erythrocyte uroporphyrinogen decarboxylase: immunological demonstration of the enzyme defect in prophyria cutanea tarda. Transactions of the Association of American Physicians. 96:65-75.

17. Toback, A. C., S. Sassa, M. B. Poh-Fitzpatrick, E. Zaider, J. Schechter, L. C. Harber, and A. Kappas. 1987. Hepatoerythropoietic porphyria. Clinical and enzymatic studies in a three generation family lineage. N. Engl. J. Med. 316:645-650.

18. Anderson, P. M., and R. J. Desnick. 1979. Purification and properties of $\delta$-aminolevulinate dehydratase from human erythrocytes. J. Biol. Chem. 254:6924-6930. 
19. Fujita, H., Y. Orii, and S. Sano. 1981. Evidence of increased synthesis of $\delta$-aminolevulinic acid dehydratase in experimental lead-poisoned rats. Biochim. Biophys. Acta. 678:39-50.

20. Chang, C. S., and S. Sassa. 1985. $\delta$-Aminolevulinate dehydratase in human erythroleukemia cells: an immunologically distinct enzyme. Blood. 65:939-944.

21. Sassa, S. 1982. $\delta$-Aminolevulinic acid dehydratase assay. Enzyme (Basel). 28:133-145.

22. Fujita, H., K. Sato, and S. Sano. 1982. Increase in the amount of erythrocyte $\delta$-aminolevulinic acid dehydratase in workers with moderate lead exposure. Int. Arch. Occup. Environ. Health. 50:287-297.

23. Fujita, H., A. Koizumi, T. Furusawa, and M. Ikeda. 1987. De- creased erythrocyte $\delta$-aminolevulinate dehydratase activity by styrene exposure. Biochem. Pharmacol. 36:711-716.

24. Bundino, S., G. C. Topi, A. M. Zina, and L. d'Alessandro Gandolfo. 1987. Hepatoerythropoietic porphyria. Paed. Dermatol. In press.

25. Romeo, P.-H., N. Raich, A. Dubart, D. Beaupain, M. Pryor, J. P. Kushner, M. Cohen-Solal, and M. Goossens. 1986. Molecular cloning and nucleotide sequence of a complete human uroporphyrinogen decarboxylase cDNA. J. Biol. Chem. 261:9825-9831.

26. de Verneuil, H., B. Grandchamp, P. H. Romeo, N. Raich, C. Beaumont, M. Goossens, H. Nicolas, and Y. Nordmann. 1986. Molecular analysis of uroporphyrinogen decarboxylase deficiency in a family with two cases of hepatoerythropoietic porphyria. J. Clin. Invest. 77:431-435. 